\title{
THE GENUS CORDAICARPUS GEINITZ IN THE LOWER PERMIAN OF THE PARANÁ BASIN, RIO GRANDE DO SUL, BRAZIL
}

\author{
JULIANE MARQUES DE SOUZA \& ROBERTO IANNUZZI \\ Departamento de Paleontologia e Estratigrafia, UFRGS, Av. Bento Gonçalves, 9500, 91509-900, Porto Alegre, RS, Brasil. \\ juliane.marques.souza@gmail.com, roberto.iannuzzi@ufrgs.br
}

\begin{abstract}
The importance of understanding reproductive strategies in Paleozoic plants has been growing due to the advances in the paleoecological studies of plant remains. Fossil seeds have an important role in these studies because of their abundance and morphological diversity. In the Rio Grande do Sul State, Brazil, many seed-containing fossil have been recovered from Morro do Papaléo, Faxinal Section and Cerro Negro outcrops. However, few studies on them have been published. This study focuses on seed specimens of the morphogenus Cordaicarpus, recovered from Lower Permian strata of the Paraná Basin in Rio Grande do Sul. The material studied is preserved as impressions/compressions mainly from the uppermost Itararé Group, but also the Rio Bonito Formation. As results, two species have been identified, Cordaicarpus aff. C. brasilianus Bernardes-de-Oliveira et al., Cordaicarpus aff. C. famatinensis Gutierrez et al., and species are described as new: Cordaiparpus cerronegrensis sp. nov. and C. truncata sp. nov.
\end{abstract}

Key words: Cordaicarpus, Lower Permian, Paraná Basin, Rio Grande do Sul State, southern Brazil.

RESUMO - A importância da compreensão das estratégias reprodutivas das plantas paleozóicas tem aumentando à medida que avançam os estudos sobre a paleoecologia desses restos vegetais. As sementes fósseis assumem um importante papel nesses estudos, uma vez que a abundância e a diversidade de formas em que são encontradas interessam aos pesquisadores. No Rio Grande do Sul, os afloramentos Morro do Papaléo, Seção do Faxinal e Cerro Negro têm fornecido fartas amostras contendo sementes, contudo, poucos estudos sobre elas têm sido publicados no estado até o presente. Visando ampliar o conhecimento das sementes e contribuir para os estudos paleoecológicos que vêm sendo realizados para o Permiano Inferior da bacia do Paraná, no Rio Grande do Sul, o presente estudo promoveu a classificação taxonômica dos diversos espécimes de sementes referentes ao morfogênero Cordaicarpus, coletados nos afloramentos já mencionados. O material estudado encontra-se preservado na forma de impressões/compressões e é proveniente, principalmente, do topo do Grupo Itararé, mas também da Formação Rio Bonito. Como resultado, são identificadas duas espécies Cordaicarpus aff. C. brasilianus Bernardes-de-Oliveira et al., Cordaicarpus aff. C. famatinensis Gutierrez et al., e foram descritas duas novas espécies: Cordaiparpus cerronegrensis nov. sp. e C. truncata nov. sp..

Palavras-chave: Cordaicarpus, Permiano Inferior, bacia do Paraná, Rio Grande do Sul, sul do Brasil.

\section{INTRODUCTION}

Reproductive biology is a primary means by which we can deepen our understanding of plant survival strategies. One of the most common sources of evidence available in the geological record is that of fossil seeds. Consequently, the knowledge of fossil seeds has become even more important, and has assumed great value to our understanding of vascular plant evolution and the dynamics of the ancient terrestrial ecosystems.

Outcrops located in the countryside from the Municipality of Mariana Pimentel, e.g. Morro do Papaléo, Faxinal Section and Cerro Negro, are among the most prominent exposures for understanding the geology and paleontological record of Permian deposits in the Rio Grande do Sul State (Iannuzzi et al., 2006, 2007; Figure 1). In fact the abundance of plant remains in these outcrops has motivated extensive investigations on this area since the middle of last century. Detailed studies have been recently carried out in these localities in order to reconstruct of the floristic paleocommunities and understand the paleoecological relations among the distinct floristic elements. In this context, the taxonomic analysis of reproductive structures, such as fossil seeds, becomes an important tool to solidify the database produced in parallel on the basis of other paleobotanical studies currently under way.

Fossil seeds attributed to the genus Cordaicarpus, as well as to the genus Samaropsis, are present in abundance in the Permian of the Paraná Basin. The seeds of these genera show different morphologies. Previously published studies, including seeds from these outcrops, span many decades (White, 1908; Corrêa da Silva \& Arrondo, 1977; Cazzulo- 
Klepzig \& Guerra-Sommer, 1984, 1985a,b; Guerra-Sommer \& Cazzulo-Klepzig, 1981, 1993, 2000). However, only the authors of the first two articles have made a complete taxonomic classification, extending their studies to a specific level, whereas the others, only went to the generic level. Thus, the fossil seeds preserved in the Municipality of Mariana Pimentel remain relatively unknown because, even though that they are abundant and morphologically diverse, specialists have not paid enough attention to them since the end of 1970's. However, in nearby São Paulo State, where stratigraphically equivalent deposits occur, many studies of seeds, to the specific level, have been published by Millan $(1965,1967,1974,1977 \mathrm{a}, \mathrm{b}, 1980,1994,1995)$ and more recently by Bernardes-de-Oliveira et al. (2007). These are an important point of comparison for the morphological analysis reported here, enlarging the available Brazilian material on which comparisons are based. In this context, a detailed analysis of the seeds from the above-mentioned outcrops will enlarge the understanding of their occurrence and stratigraphic distribution in the Lower Permian strata of the Rio Grande do Sul State.

This paper gives continuity to a previous study that began with the publication of seeds belonging to genus Samaropsis Goeppert (Souza \& Iannuzzi, 2007), analyzing herein the seeds classified in genus Cordaicarpus Geintz.

\section{GEOLOGY}

The Municipality of Mariana Pimentel is located at approximately $100 \mathrm{~km}$ southwest of Porto Alegre, capital of Rio Grande do Sul. In this area, there are good exposures of Lower Permian-rocks, and an abundant record of plant remains. For the present study, the seeds recovered from Morro do Papaléo, Faxinal Section and Cerro Negro outcrops are presented (Figure 1).

\section{Morro do Papaléo outcrop}

Among the outcrops studied, the Morro do Papaléo, an abandoned opencast mine, has received the most attention of researchers, and furnished most of the plant material analyzed herein. The stratigraphic profile of this outcrop used in this study was proposed by Iannuzzi et al. (2003a,b; 2006; 2007), the uppermost portion of outcrop contains the phytofossiliferous levels. Only the seed-containing levels are described below (Figure 2).

The lowermost fossiliferous Level N2 consists of horizontally bedded heterolithic units, composed of alternating siltstones and light to medium grey, finely laminated shales. The flora consists of impressions of fronds of Botrychiopsis plantiana and leaves of Gangamopteris obovata, Glossopteris communis and Cordaites hislopii, besides the Samaropsis and Cordaicarpus seeds (Iannuzzi et al., 2006).

The fossil Level N4, which is stratigraphically situated at the uppermost portion of Itararé Group, is composed of light grey to reddish, horizontally laminated siltstones and siltymudstones, in which have been preserved abundant plant impressions corresponding to stems (Paracalamites-type), rhizomes (Pinnularia-type), leafy shoots related to Phyllotheca australis $(=P$. indica) and Stephanophyllites cf. sanpaulensis, foliage assigned to Glossopteris communis, G. indica, G. occidentalis, Gangamopteris obovata, G. buriadica, Gangamopteris sp. 1, Gangamopteris sp. 2, Cordaites hislopii, Cheirophyllum speculare, Kawizophyllum sp. and ?Dicranophyllum sp. (Iannuzzi et al., 2006), and seeds of the Samaropsis-type, e.g. S. gigas, S. kurtzii, S. aff. rigbyi, Samaropsis sp. 1 and Samaropsis sp. 2 (Souza \& Iannuzzi, 2007), and the Cordaicarpus-type, the last the subject of this paper.

The fossiliferous levels N7 and N8 are situated in the uppermost part of this outcrop, considered as belonging to the Rio Bonito Formation, Guatá Group. They consist of white to light grey, massive to horizontally laminated siltymudstone, lenticular layers up to $2 \mathrm{~m}$ thick, interbedded with white, coarse- to very coarse-grained tabular sandstones with undulate and erosive contacts, showing internally sets of planar and trough cross-bedded sandstone. Some of the plant specimens studied here were found in the silty-mudstone bodies and consist of seeds of the Samaropsis-type (S. gigas, S. aff. millaniana, Samaropsis sp. 1, Samaropsis sp. 2; Souza \& Iannuzzi, 2007) and Cordaicarpus-type. In association with these specimens: many impressions of Brasilodendron pedroanum and Cyclodendron sp.; leaves of Glossopteris communis, G. indica, G. occidentalis, Gangamopteris obovata var. major, Cordaites hislopii, Kawizophyllum sp. and Ginkgophytopsis sp.; and fronds of Pecopteris pedrasica, Pecopteris sp., Asterotheca sp., Sphenopteris sp. and Neomariopteris sp., as well as rare Arberia-type fructifications (Iannuzzi et al., 2006; Vieira et al., 2007).

Iannuzzi et al. (2003a,b; 2007) have proposed that the levels N1 and N4 correspond to deposits of marginal environments, lagoonal to lacustrine systems, whereas levels N7 and N8 represents strata typically found in flood plains and other subenvironments associated with channel deposits of a braided fluvial system.

\section{Faxinal Section outcrop}

The Faxinal Section outcrop has not been described before. It is located at about $500 \mathrm{~m}$ southwest of Morro do Papaléo outcrop. However, the Faxinal Section corresponds to the "white facies" found in the basal portion of the Faxinal outcrop, an exposure situated near this area, which was described by Corrêa da Silva $(1970,1978)$ and Andreis et al. (1979). Due to this lithological similarity, this exposure is named herein as "Faxinal Section".

The "white facies" of Faxinal Section outcrop, which is predominantly light grey in color, is composed of horizontally bedded finely laminated heterolithic units. A not welldeveloped paleosoil is also registered in this exposure. Upwards of the section, the mudstone and the fine-grained sandstones are the most common lithologies. This facies, assigned to the lowermost portion in the Faxinal Outcrop, has been interpreted by Andreis et al. (1979) as a lacustrine environment (or lagoonal, authors op.) of shallow but stable 

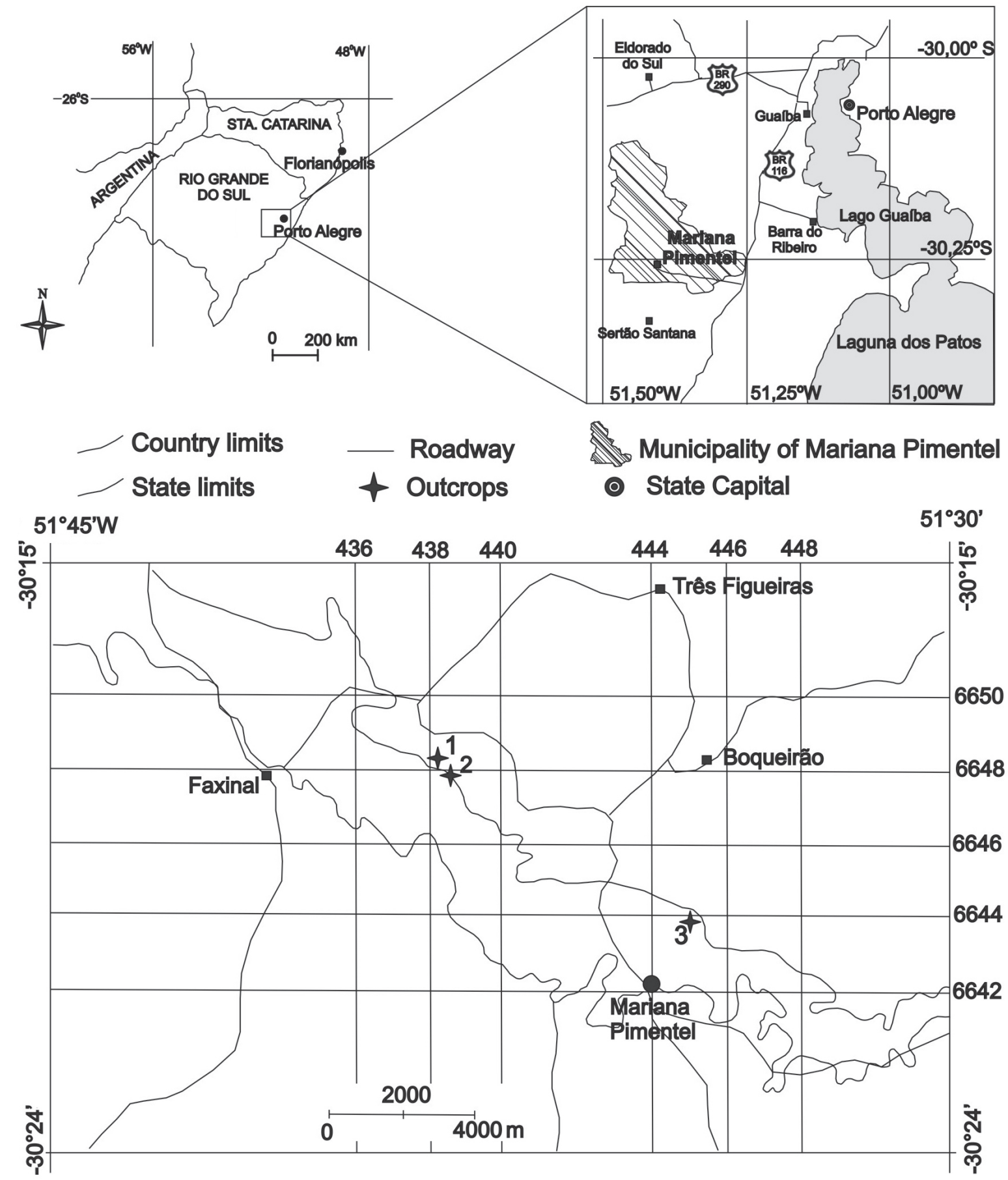

Figure 1. Map of the Mariana Pimentel Municipality, in eastern Rio Grande do Sul with the location of the outcrops: 1, Morro do Papaléo; 2 , Faxinal section; 3, Cerro Negro (mod. from lannuzzi et al., 2006 and Paim et al., 1983).

waters. Actually, the well preserved plants remains, the presence of paleosoil and the sedimentary structures suggest that this deposit was generated in marginal environment of lenthic-type water bodies.

In the Rio Grande do Sul State, this facies is stratigraphically situated at the uppermost portion of Itararé Group and represents the last stage of sedimentary in-filling of large lakes at the end of the post-glacial sedimentary cycle of this unit (Côrrea da Silva, 1978; Andreis et al., 1979). Considering the fossil record, leaves of Glossopteris communis and Gangamopteris spp., small stems (Paracalamites-type) and leaf shoots related to genera Phyllotheca and Stephanophyllites, as well as many fragmented fronds of Botrychiopsis plantiana, have been recovered from this exposure.

The Faxinal Section outcrop contains a taphoflora similar to the one found at Faxinal outcrop, and corresponds stratigraphically to the same interval, according to data published by Côrrea da Silva (1978) and Guerra-Sommer et al. (1980). 


\section{Cerro Negro outcrop}

The last outcrop that furnished samples for the present study is Cerro Negro. Few prior studies have taken this outcrop into account; the only one being that of Delaney (1964). According to Delaney (1964:166), the stratigraphic section in general consists of basal conglomerates (facies 1), followed upwards by fine-grained sandstones and clayeysiltstones (facies 2), which are overlaid with carbonaceous shales and siltstones (facies 3), occasionally interbedded with lenses of limestones and quartz sandstones, finishing at top with a thick covering of conglomeratic, quartz sandstones interbedded with sandy siltstones (facies 4). No information about the fossil content of this outcrop is furnished by the author. However, the samples collected for this study reveal leaves of Glossopteris and Cordaites and seeds of genus Samaropsis, corresponding to facies 3 (= carbonaceous shales and siltstones).

\section{MATERIAL AND METHODS}

For determination of the distinct morpho-groups we used the same criteria for descriptive analysis commonly accepted by most authors who have studied Paleozoic seeds. These include the follow characteristics proposed by Oliveira \& Pontes (1976, revalued by Millan, 1994), Taylor \& Taylor (1993), Millan (1994) and Archangelsky (2000): (i) symmetry axis: platispermic versus radiospermic; (ii) shape and differentiation of testa into sarcotesta, sclerotesta and endotesta; (iii) shape and surface of nucellus; (iv) relation between maximum width of testa and maximum width of nucellus $(=\mathrm{WT} / \mathrm{WN})$; (v) presence or absence of the median ridge on the nucellus; (vi) establishment of the seed length from the longest seed measurement obtained parallel to the symmetry axis; (vii) establishment of seed width measured transverse to the symmetry axis; and (viii) thickness as an expression of the testa measurements. These criterions are useful with seeds preserved as compressions and impressions because they are applicable to flat and bi-dimensional structures. Once the morphometric analysis was concluded, the comparison with the Gondwanan seeds already described was carried out. For this last task, the work of Millan (1994) was used extensively, and was the start point for the comparative analysis.

All of the material examined is preserved as either compressions or impressions. This fact should be constantly taken into account because the preservation quality can create morphological distortions which can induce to the erroneous interpretations, once some plant structures do not get preserved or suffer an irregular flattening that change their original shape. These taphonomic biases could be accounted for or even reduced by a morphologic analysis using a large number of specimens, which allows a more accurate examination of the small distortions present, in order to decide whether or not they can be considered as diagnostic features.

The material studied are housed at the Departamento de Paleontologia e Estratigrafia (DPE), Instituto de Geociências
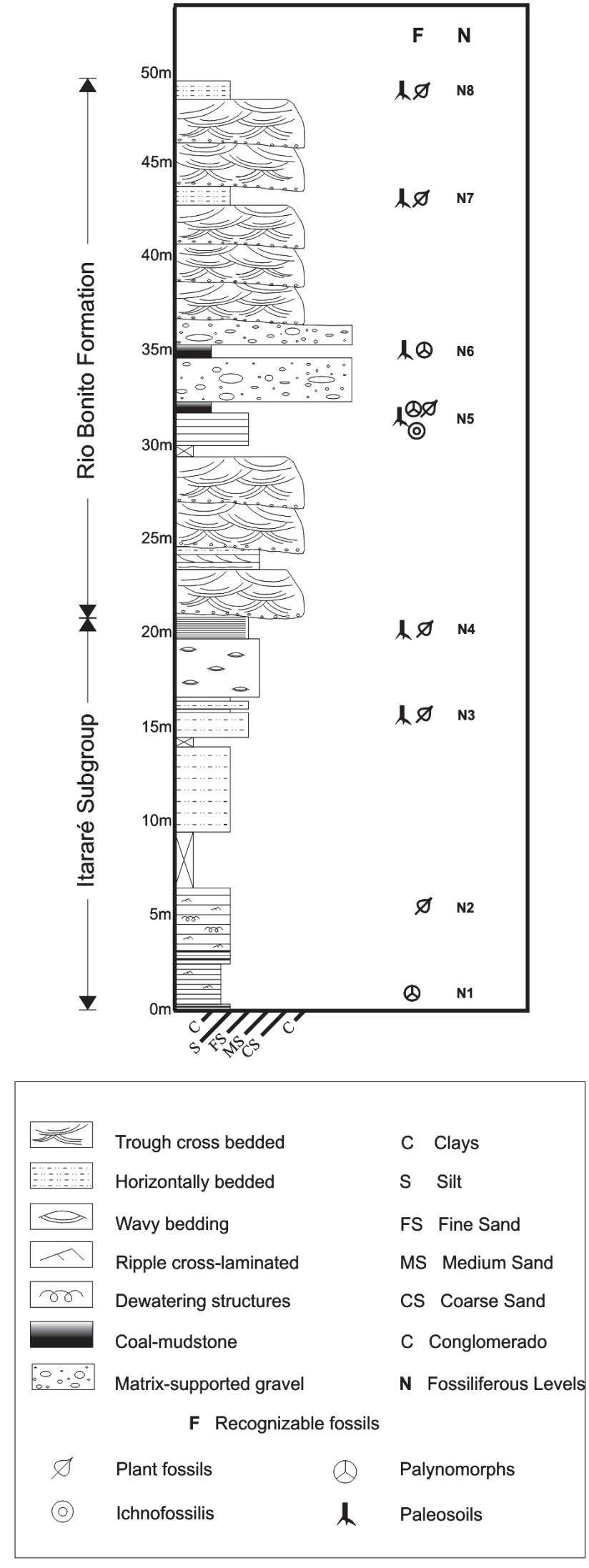

Figure 2. Stratigrafic section of the Morro do Papaléo outcrop showing the plant-bearing levels as described in the text (mod. from lannuzzi et al., 2007). 
(IG), Universidade Federal do Rio Grande do Sul (UFRGS), under MP-Pb code. In the register number, small letters identify part and counter-part of a same sample, as for instance MP-Pb 4392a and MP-Pb 4392b, whereas capital letters identify the different specimens found in the same rock sample, as for instance MP-PB $2608 \mathrm{~A}, \mathrm{MP}-\mathrm{Pb} 2608 \mathrm{~B}$ and MP-Pb $2608 \mathrm{C}$.

\section{SYSTEMATIC PALEONTOLOGY}

The genus Cordaicarpus was originally erected by Geinitz (1862), but afterwards Seward (1917: 354) re-defined it to avoid confusion with other genera already described, affirming that this genus refers to "platyspermic seeds preserved as casts or impressions, having a comparatively narrow border enclosing an ovate or cordate-ovate nucule". Seward established the differences between Cordaicarpus and Samaropsis, indicating that the last genus is distinguished, according to the author, by its differentiated testa composed of one inner narrower border and the other outer and more delicate border. Later, complementary diagnostic characters were proposed by Maithy (1965) and Millan (1974), allowing inclusion in the genus Cordaicarpus specimens that present a narrow sarcotesta, with or without median ridge, and obtuse or acuminate apex.

According to Millan (1994), the first step to define either genus of Paleozoic seed in Gondwana is to verify the presence, or not, of a differentiated testa. Considering those cases where due to preservational reasons the testa differentiation is not evident, one can use the method proposed by Oliveira \& Pontes (1976), afterwards reevaluated by Millan (1994), in which the specimens that present a ratio between maximum width of testa and maximum width of nucellus (WT/WN) over or equal to $0.22(\geq 1 / 4,5)$ should be assigned to the genus Samaropsis, whereas the ones that show this relation under $0.22(<1 / 4,5)$ belong to Cordaicarpus.

Archangelsky (2000), in her revision on the main genera of Paleozoic seeds, has concluded that the genus Cordaicarpus is composed of "impressions and compressions of platyspermic seeds, with ovate to circular outline and acuminated to slightly emarginated apex, without extending beyond the border of the main body of the seed; the sarcotesta is narrow when present".

For the present study, the differentiated testa was used as the main distinctive character separating the genera Samaropsis and Cordaicarpus. At the intermediary cases, the method proposed by Oliveira e Pontes (1976) and Millan (1994) was used to justify the inclusion of the specimens in Cordaicarpus.

Finally, it is important to emphasize that, according to Oliveira e Pontes (1976), in Brazil, the genus Cordaicarpus was previously designed by authors such as White (1908) and Oliveira (1935) as either Cardiocarpon or Cardiocarpus, being corrected by Millan (1965) after he considered the generic emendation proposed by Seward (1917).

\author{
GYMNOSPERMAE \\ Semina Incertae Sedis \\ Cordaicarpus Geinitz 1862
}

Cordaicarpus cerronegrensis sp. nov. (Figure 3)

Holotype. MP-Pb 2608C.

Paratypes. MP-Pb 2608A, B, D; 2613A-E; 4392a/bA-D; 4393A.

Locality. Cerro Negro and Faxinal Section, in Mariana Pimentel, Rio Grande do Sul.

Occurrence. uppermost Itararé Group and Rio Bonito Formation. Age. Early Permian (Late Sakmarian-Early Artinskian).

Etymology. From the name given to the fossiliferous site Cerro Negro from which the holotype specimen was recovered.

Diagnosis. Platyspermic seeds; general outline oval showing surface densely striated, length from 4.6 to $7.0 \mathrm{~mm}$ and width between 2.6 and $3.7 \mathrm{~mm}$. Elongated, acute apex, rounded base with scar at point of attachment to seed stalk. Nucellus follows same outline as seed except for apical portion where it tapers to a sharp acute apex; a longitudinal striated surface, furrows converge at both apical and basal portions. Testa is undifferentiated and also striated like nucellus, becoming widest towards apical portion.

Description. Striated seeds, bilateral symmetry, general outline oval at the longitudinal axis, with elongated and acute apex and rounded base (Figure 3A). This seed is characterized by a variable length, between 4.6 to $7.0 \mathrm{~mm}$, and a width from 2.6 to $3.7 \mathrm{~mm}$.

The nucellus, the innermost part of the seed, has an acute apex and a rounded base, with 4.0 to $5.8 \mathrm{~mm}$ in length and 2.0 to $2.8 \mathrm{~mm}$ in width. There is no evident median ridge. The micropyle appears like a "V" at the apex (Figures 3 A-B, A'B'). The striations run lengthwise on the nucellus surface and converge at the apex and base, following the shape of the seed.

The testa is undifferentiated, striated, with a general oval outline, acute apex and rounded base. The thickness of the testa is variable surrounding the nucellus: the basal portion is thinnest, measuring between 0.2 and $0.3 \mathrm{~mm}$, thickening at the nucellus apical portion, where it measures 0.4 to $0.9 \mathrm{~mm}$ (Figures $3 \mathrm{~A}^{\prime}-\mathrm{B}^{\prime}$ ). At the base in many specimens, the insertion scar of the seed on the fructification can be seen (MP-Pb $4392 \mathrm{a} / \mathrm{b}$; Figure 3). The relation between maximum width of testa and maximum width of nucellus $(\mathrm{WT} / \mathrm{WN})$ is between 0.08 and 0.19 .

Discussion and comparison. According to the method proposed by Oliveira \& Pontes (1976) and revalued by Millan (1994), the WT/WN relations obtained from the specimens include them in the genus Cordaicarpus.

They are seeds characterized by an acute apex, rounded base and striated surface. The large amount of specimens examined allows a high level of reliability in determination of the morphological characters and in the morphometrical data obtained, minimizing possible preservational problems.

The Maithy scheme (1965), changed later by Millan (1974a:tab.9; 1994:tab.1), permits a systematic classification 

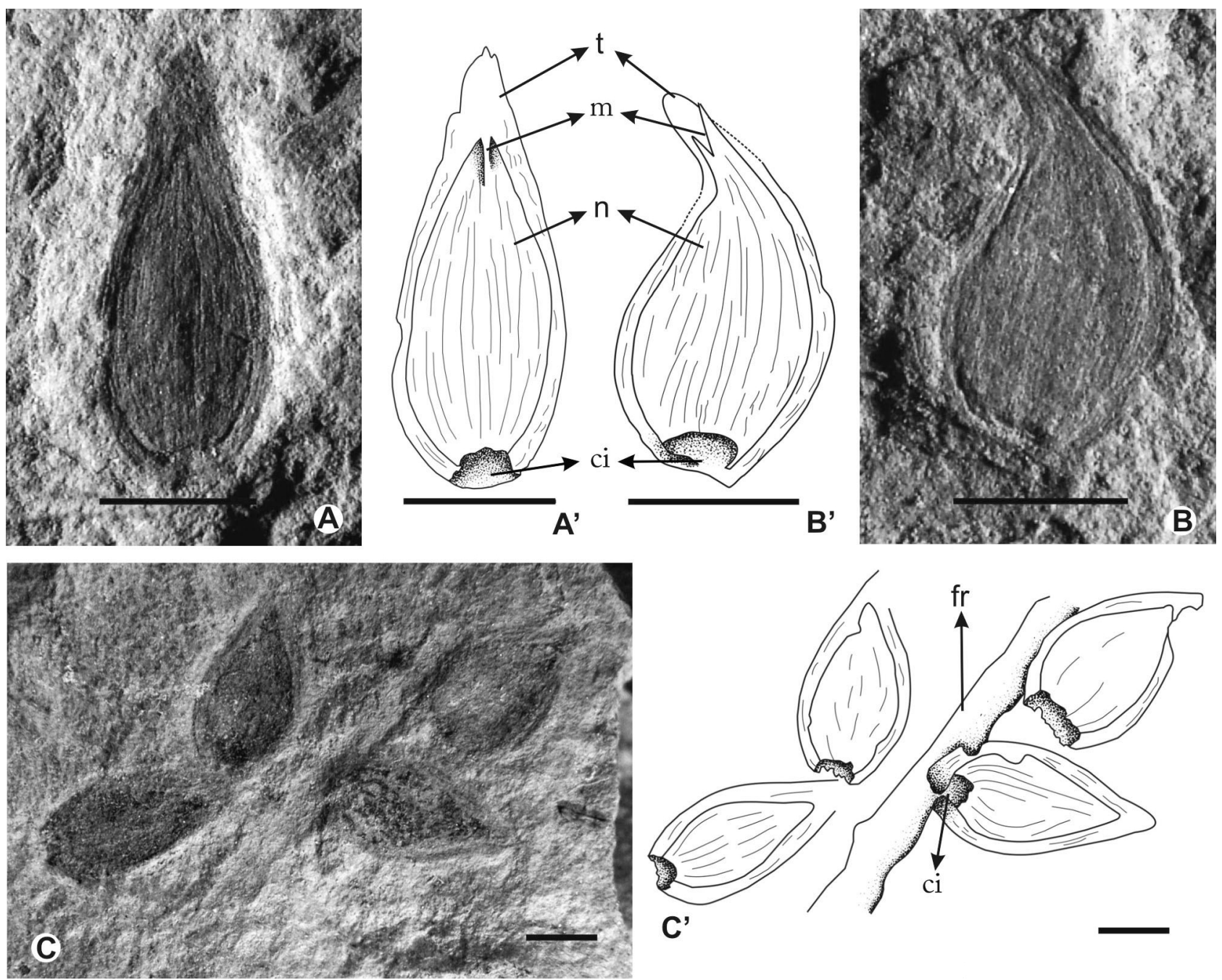

Figure 3. Cordaicarpus cerronegrensis sp. nov., from Cerro Negro and Faxinal Section. A, MP-Pb 2808C, holotype, complete specimen; $\mathbf{A}^{\prime}$, holotype drawing showing the testa thickening at the apical portion, the V-shape micropyle, the striated nucellus, and the scar of the seed insertion on the fructification; B, MP-Pb 2608A, paratype, showing a curvature in the seed, suggesting a probable taphonomic feature; B', MP-Pb 2608A, indicating the V-shaped micropyle opening; C, paratype, MP-Pb 4392b, fructification with seed insertion position, and detachment process scars; C', fructification with the insertion scars. Abbreviations: ci, insertion scar; fr, fructification; m, micropyle; $\mathbf{n}$; nucellus; $\mathbf{t}$, testa. Scale bars $=2 \mathrm{~mm}$.

of all Paleozoic seed groups preserved as compressionsimpressions. Using this system, the material studied can be described as platispermic seeds, without median ridge, with obtuse/acute apex or acuminate. From this, some comparisons can be made with others species already described at the literature, such as: Cordaicarpus ovatus, C. rocha-camposii, C. acuminatus, C. chicariensis, C. irapuensis, C. zeillerii, C. emarginatus, C. mucronatus and C. prolatus.

Cordaicarpus ovatus Walkom (1935: 461, pl.19, fig.8) and Cordaicarpus rocha-camposii Oliveira (1976: L44, pl.4, figs.911) have a general rounded shape and a smooth surface, and, in this way, are not comparable with the material examined herein.

Cordaicarpus acuminatus Gutierrez, Ganuza, Morel \& Arrondo (1992:52, pl.1, figs.1-8, pl.2, figs.6,8) shows an acuminate apex and base, Cordaicarpus chicariensis Lele (1963:13, pl.1, fig.1, fig.-tex.1) has a short conical beak at the apex. Cordaicarpus irapuensis Oliveira (1976:L48, pl.4, figs.6-
8) shows the larger testa thickness at the side of the seed. Thus, none of these species have a general shape similar to the specimens described herein.

Although Cordaicarpus zeillerii Maithy (1965:45, pl.1, figs.1-3, figs.-text.1,2) has a uniform testa thickness and a general rounded shape, it differs from the material analyzed due to its non uniform testa thickness and oval shape. Cordaicarpus emarginatus Walkom (1935:462, pl.19, fig.11), a species from Australia, though poorly preserved, is described as having an acuminate and emarginate apex, and an acuminate base, differing considerably from features observed in Brazilian material. The pointed apices of Cordaicarpus mucronatus Hoeg \& Bose (1960:48, pl.11, figs.2,3) and Cordaicarpus prolatus Walkom (1935:461, pl.19, fig.6), as well as the median ridge present at the basal portion of the later species, make them unlike the material analyzed.

Thus, considering the clear morphological differences from all similar species described in the literature, and the 
relatively large amount of material studied, the specimens described herein can be considered as a new species.

\section{Cordaicarpus truncata sp. nov.}

(Figure 4)

Holotype. MP-Pb 3969B.

Paratypes. MP-Pb 3968A; 3969B, C; 3972 A, B.

Locality. Morro do Papaléo outcrop, in Mariana Pimentel, Rio Grande do Sul.

Occurrence. Fossiliferous level 2 (=N2), uppermost Itararé Group, according to Iannuzzi et al. (2003a,b; 2006).

Age. Early Permian (Late Sakmarian).

Etymology. From its truncate base, the main diagnostic feature of the new species.

Diagnosis. Seeds with bilateral symmetry, striated surface, acute to acuminate apex and truncate base. Length from 7.7 to $9.0 \mathrm{~mm}$, and width between 4.4 and $5.6 \mathrm{~mm}$. Basal portion of nucellus shows same shape as basal most part of seed, while the apex varies from obtuse to slightly acute. Testa is narrowest at the lateral sides, wider and acuminated at the apex and widest at base portion where it is truncated, forming an irregular margin that probable corresponds to original area of connection between seed and mother-plant. Without median ridge preserved.

Description. Striated seed, with bilateral symmetry, general oval outline, with an acute apex that can be acuminate and a truncate base (Figure 4A). It is characterized by a variable length, between 7.7 and $9.0 \mathrm{~mm}$ and variable width from 4.4 to $5.6 \mathrm{~mm}$.

The striated testa has a constant thickness on the seed side, measuring around $0.3 \mathrm{~mm}$. At the apical portion, the testa is extended into an acuminate shape, and at the base considerably thickens, reaching $0.8 \mathrm{~mm}$ in width, where it is truncated in shape, widened and with an irregular outline, as if it were the insertion point of the seed on the mother-plant (Figure 4).

The nucellus is densely striated, with an obtuse to lightly acute apex and widened base. The basal portion is the same in outline shape as the overall seed, and is between 3.0 and $4.2 \mathrm{~mm}$ in length and from 6.2 to $8.3 \mathrm{~mm}$ in width (Figure 4). In some specimens (MP-Pb 3969A) it is possible to see the emarginate micropyle, which can appear opened like a "V" shape (Figure 4). There is no median ridge preserved. The ration of maximum width of testa and maximum width of nucellus (WT/WN) ranges from 0.08 to 0.19 .

Discussion and comparison. According to the method proposed by Oliveira \& Pontes (1976) and reevaluated by Millan (1994), the material studied is classified into the genus Cordaicarpus, considering the low values obtained from the ratio $\mathrm{WT} / \mathrm{WN}$.

The most important characteristic of these specimens is the truncate shape of their base, which seems to correspond to a wide point of insertion at the fructification. In association with the apex this base makes the morphology of these seeds unique.

Applying the scheme organized by Maithy (1965) and modified by Millan (1974a, tab.9; 1994, tab.1), the seeds examined are classified among those with "bilateral symmetry, narrow and undifferentiated testa, without median ridge and with obtuse/acute or acuminate apex". Among the species that are include in this group, only the species Cordaicarpus acuminatus Gutierrez et al. (1992:52, pl.1, figs.1-8, pl.2, figs.6, 8), Cordaicarpus mucronatus Hoeg \& Bose (1960:48, pl.11, figs.2,3) and Cordaicarpus prolatus Walkom (1935:461, pl.19, fig.6) show some similarity with the material studied.

Cordaicarpus acuminatus, from the Late Paleozoic of Argentina, differs basically in terms of the base shape of the seed, which has an acuminate shape described by the authors as a conic or spine-like projection. The Brazilian material, in contrast, has a base with truncate shape. This difference in the base shape removes any possibility that the material analyzed can be classified as C. acuminatus.

Cordaicarpus mucronatus, a species from the Permian of Congo, has the apex with the same kind of projection as that found in the studied specimens. However, its base has not been described by Hoeg \& Bose (1960). There is a single illustration of the type-specimen (Hoeg \& Bose, 1960:48, pl.11, figs.2,3), which does not allow inference of a truncate base, as seen in the Brazilian specimens. Finally, according to the original description, the testa is narrow and no thickening is evident in C. mucronatus, differing from material studied herein.

Cordaicarpus prolatus, present in Upper Paleozoic deposits of Australia, shows a pointed apex and an undifferentiated testa. The species was erected based on a single specimen, where the author does not describe any kind of testa thickening. The seed base shows a projection that unlike the truncate shape found in bases of the specimens described herein. Furthermore, comparison can be made only on a less detailed description (Walkom, 1935:461) and a single photo taken from type specimen (Walkom, 1935:pl.19, fig.6). Even so, it is clear that the specimens studied do not belong to the Australian species.

Among the three species described in the literature, that have some similarity with the studied specimens, none of them show a similar base shape as described herein. Considering this feature as the diagnostic characteristic, the present specimens can be assigned as a new species, named Cordaicarpus truncata sp. nov.

Cordaicarpus aff. C. brasilianus Bernardes-de-Oliveira, Castro-Fernandes, Tewari \& Ricardi-Branco 2007

(Figure 5D-G)

Material. MP-Pb 3233; 3674; 3682A; 3735; 3746; 3751A, B; 3753; 3950A, B; 3943A; 3962; 3964; 3966A.

Locality. Morro do Papaleó outcrop, in Mariana Pimentel, Rio Grande do Sul.

Occurrence. Fossiliferous level 4 (=N4), uppermost Itararé Group; and fossiliferous level $7(=\mathrm{N} 7)$ and $8(=\mathrm{N} 8)$, Rio Bonito Formation, according to Iannuzzi et.al. (2003a,b; 2006). Age. Early Permian (Late Sakmarian - Early Artinskian).

Description. Small seed, smooth, with bilateral symmetry, 

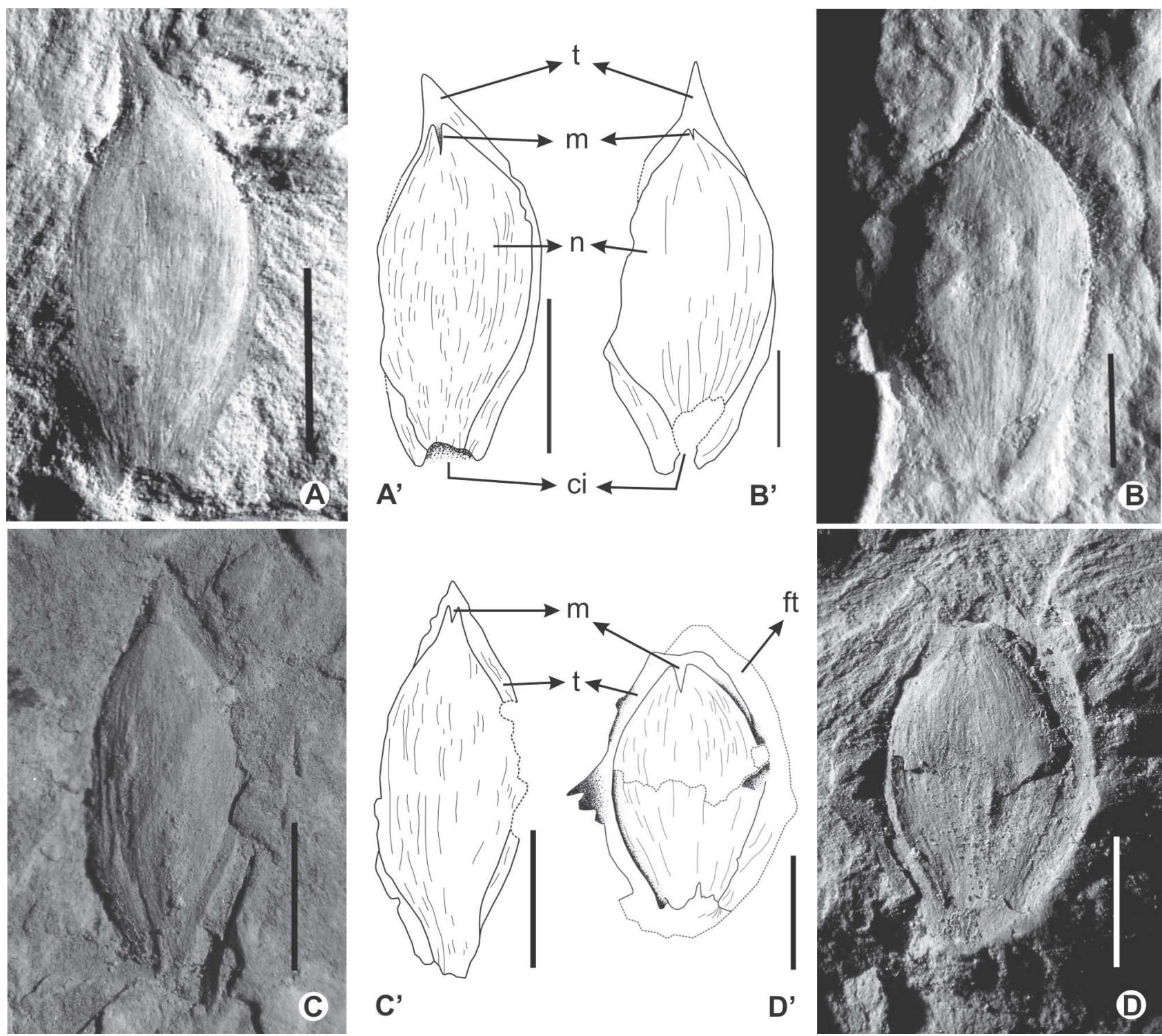

Figure 4. Cordaicarpus truncata sp. nov., Morro do Papaléo, RS. A, MP-Pb 3969B, holotype, complete specimen with a truncate base (diagnostic feature) and enlarged testa at this region; A', holotype drawing indicating the micropyle, the striated surface and the scar of the seed insertion on the mother plant; B, MP-Pb 3972A; paratype, B', MP-Pb 3972A, with the same features of the holotype; C, paratype MP-Pb 3968A, C', MP-Pb 3968A, showing a specimen with incomplete testa preservation at the side portion; D, MP-Pb 3969A, paratype, showing incomplete testa on apical and basal portions; D', MP-Pb 3969A, indicating the micropyle and the seed dislocation, interpreted as a taphonomic feature. Abbreviations: $\mathbf{c i}$, insertion scar; $\mathbf{f t}$, taphonomic feature; $\mathbf{m}$, micropyle; $\mathbf{n}$; nucellus; $\mathbf{t}$, testa. Scale bars $=3 \mathrm{~mm}$.

outline from oval to almost circular, with rounded base and apex, in some specimens, slightly obtuse (Figure 5F-G). Characterized by a variable length, between 3.2 and $4.9 \mathrm{~mm}$ and width from 2.5 to $4.3 \mathrm{~mm}$.

These seeds have an undifferentiated testa, with a more or less circular outline. Apex and base follow the same general shape as the seed, measuring around 0.2 and $0.5 \mathrm{~mm}$. The nucellus also follows the seed shape; it has an obtuse apex and a rounded base, and is 2.6 to $4.7 \mathrm{~mm}$ in length and 2.2 to $3.9 \mathrm{~mm}$ in width (Figure 5D-G). In some specimens is possible to see a low median ridge in the apical portion of the nucellus (MP-Pb 3962). The ratio between maximum width of testa and maximum width of nucellus (WT/WN) is 0.07 to 0.16 .

Discussion and comparison. These specimens are characterized by their circular to oval shape, the smooth surface and the absence of a prominent median ridge. The $\mathrm{WT} / \mathrm{WN}$ ratio obtained classifies them in the genus Cordaicarpus.

Among the species described in the literature, some of them have a similar morphology compare to those mentioned above. The Australian species Cordaicarpus prolatus Walkom (1935:461, pl.19, fig.6) and Cordaicarpus ovatus Walkom (1935:461, pl.19, fig.8), even though they have similar morphology to the material described herein, show a pointed or acuminate apex, being in this way distinct from the Brazilian material. Is important to emphasize that both species were superficially described by Walkom, and to get a better comparison the present authors were limited to use of the 
photo furnished in that paper.

Another species that shows some similarity with the specimens examined is Cordaicarpus chicariensis Lele (1963:13, pl.1, fig.1, fig.-text.1), because of the presence of testa with uniform width surrounding the nucellus. Nevertheless, this testa projects into a short conical beak at the apex, making this apex quite different from that presented by the material described herein.

Cordaicarpus irapuensis Oliveira (1976:L48, pl.4, figs.68), recovered from the Rio Bonito Formation in Criciúma, SC, is similar to the Brazilian material in terms of the general oval/ rounded outline, the smooth surface, and the micropile difficult to see. However, C. irapuensis has an acuminate apex rather than the obtuse apex as in the material described herein. In addition, the base in C. irapuensis is not rounded but slightly cordate and, finally, its testa does not show a continuous thickness surrounding the nucellus, but enlarges at the lateral sides of the seed.

Another species described that shows some similarity with the specimens studied is Cordaicarpus rocha-camposii Oliveira 1976(Oliveira \& Pontes, 1976:L44, pl.4, figs.9-11, figstext.11, 12), from the Rio Bonito Formation, in Criciuma, SC. Comparing both forms, a high degree of similarity is evident in the shapes of the apical and basal portions and in the continuous testa thickness. However, in C. rocha-camposii, some specimens show fine striations at the basal portion that, according to Oliveira \& Pontes (1976), may be vascular scars. Another difference is recognized in the total size of the seed, which is larger in C. rocha-camposii than in the material described in this study.

The last species that allows some comparison is Cordaicarpus brasilianus Bernardes-de-Oliveira et al. (2007:5, pl.1, figs.1-2, fig.-text.4a-d), which was recently described, from the upper portion of Itararé Group, in Cerquilho, São Paulo State. This species is extremely similar to the material of this study. The general shape of the seed, the general size and the testa thickness are equivalent. However, the presence of fine striations and mainly the acuminate apex in C. brasilianus make it different from the specimens examined in this study, which have an obtuse/ acute apex and a smooth surface. Taking into account that this difference can be an outcome of preservational factors, or even an intra-specific variation, the material presented herein can be determined to be very similar to Cordaicarpus brasilianus.

Cordaicarpus aff. C. famatinensis Gutierrez, Ganuza, Morel \& Arrondo 1992

(Figure 5A-C)

Material. MP-Pb 3652A-C; 3696A, B; 3954A; 3980a/b. Locality. Morro do Papaléo outcrop, in Mariana Pimentel, Rio Grande do Sul.

Occurrence. Fossiliferous level $4(=\mathrm{N} 4)$, uppermost Itararé Group, according to Iannuzzi et al. (2003a,b).

Age. Early Permian (Late Sakmarian).

Description. Small seed, smooth, with bilateral symmetry, general outline circular to elliptical, emarginate apex and rounded base. Characterized by variable length between 4.7 and $5.5 \mathrm{~mm}$, and width from 3.3 to $4.0 \mathrm{~mm}$.

The testa of this seed is undifferentiated with thickness from 0.2 to $0.4 \mathrm{~mm}$ at the basal and side portions, enlarging in the apical portion, where the thickness averages from 0.6 to $0.7 \mathrm{~mm}$ (Figure 5A-C). The nucellus has an acute apex and a rounded base, with length between 4.1 and $5.0 \mathrm{~mm}$ and width that varies from 2.7 to $3.2 \mathrm{~mm}$. In some species is possible to see an emarginate micropyle (Figure 5A). There is no apparent preservation of the median ridge. The ratio of maximum width of testa/maximum width of nucellus (WT/WN) varies from 0.12 to 0.18 .

Discussion and comparison. Due to the small amount of material found of this morphotype, a detailed description, which could allow evaluating of the probable intra-specific variations, could not be carried out. However, the specimens can be classified by their general morphological characteristics and the WT/WN ratio obtained places them in the genus Cordaicarpus.

Among the species described in the literature, the material of this study can be compared with Cordaicarpus cesarii Gutierrez et al. (1992:54, pl.2, figs.1, 2 e 4, fig.2), from the Tupe Formation, and Cordaicarpus famatinensis Gutierrez et al. (1992:56, pl.4, figs.1-5, fig.3), from the Água Colorada Formation, both from the Pennsylvanian of Argentina. This comparison is possible due to the fact that both Argentinean species and the material examined herein show a testa thickening at the apical portion of seed. However, in the Brazilian specimens, the testa, at its micropylar region, ends in two acute arms, such as occurs in C. famatinensis, a feature that makes it unlike C. cesarii.

As well as the testa morphology, the material of this study and $C$. famatinensis share a similar general shape. Although the Brazilian specimens have a general size slightly lower than the Argentinean species, morphometric characters, when seen alone, are not considered as a good diagnostic criteria for compressed-impressed seed classification, because size can vary according to the degree of maturation of the seeds.

However, there are other two characteristics that prevent the direct classification of the Brazilian specimens into $C$. famatinensis. First, is the presence of an apical sinus, at the micropyle region of $C$. famatinensis, which is not found in the material analyzed. However, this sinus can be interpreted as an opening at the micropylar region caused by a possible fertilization (biologic feature), or also as a deformation caused by compression, which, depending the level of seed maturation, could cause a disruption of the micropylar region (taphonomic feature). Second, there is the presence of a faint median ridge found at some specimens of the Argentinean material; this feature is not evident in any of the Brazilian specimens (Figure 5A-C).

Taken into account the similarities found, the fragility of differences observed, and the few amount of specimens analyzed in this study, the material examined can be consider relatively similar to Cordaicarpus famatinensis. In the future, the enlargement of the sample number associated with a new 

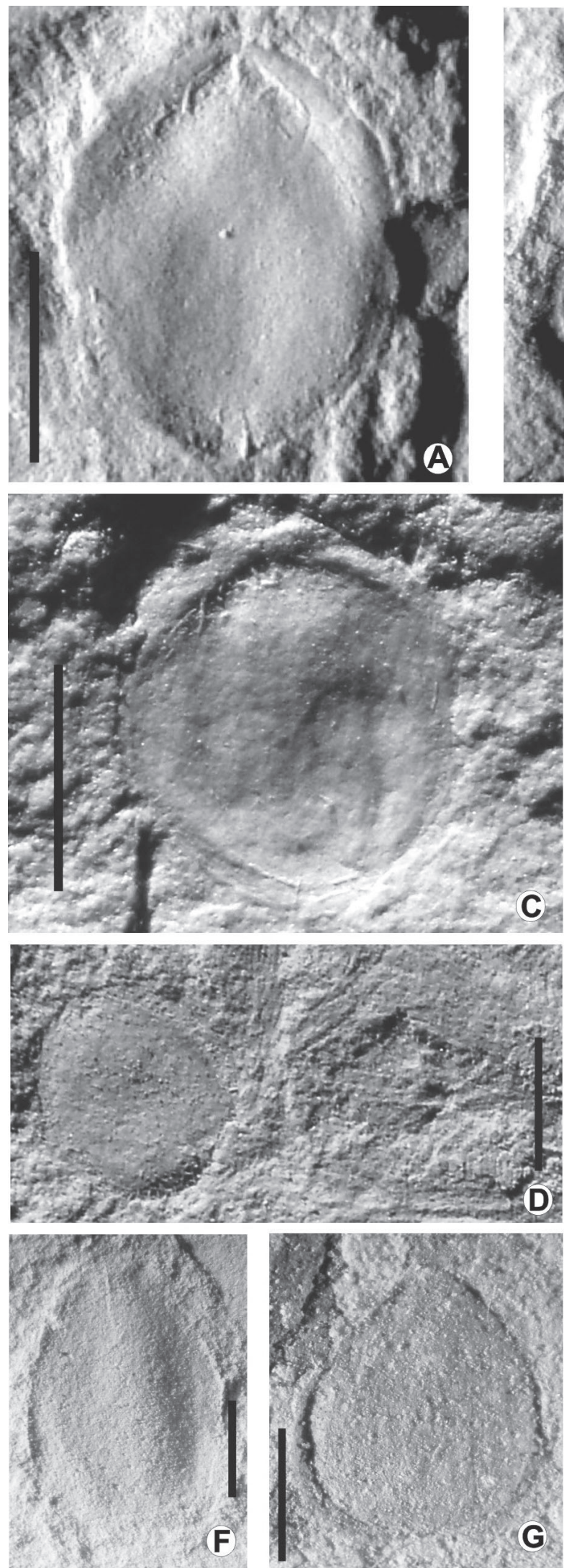
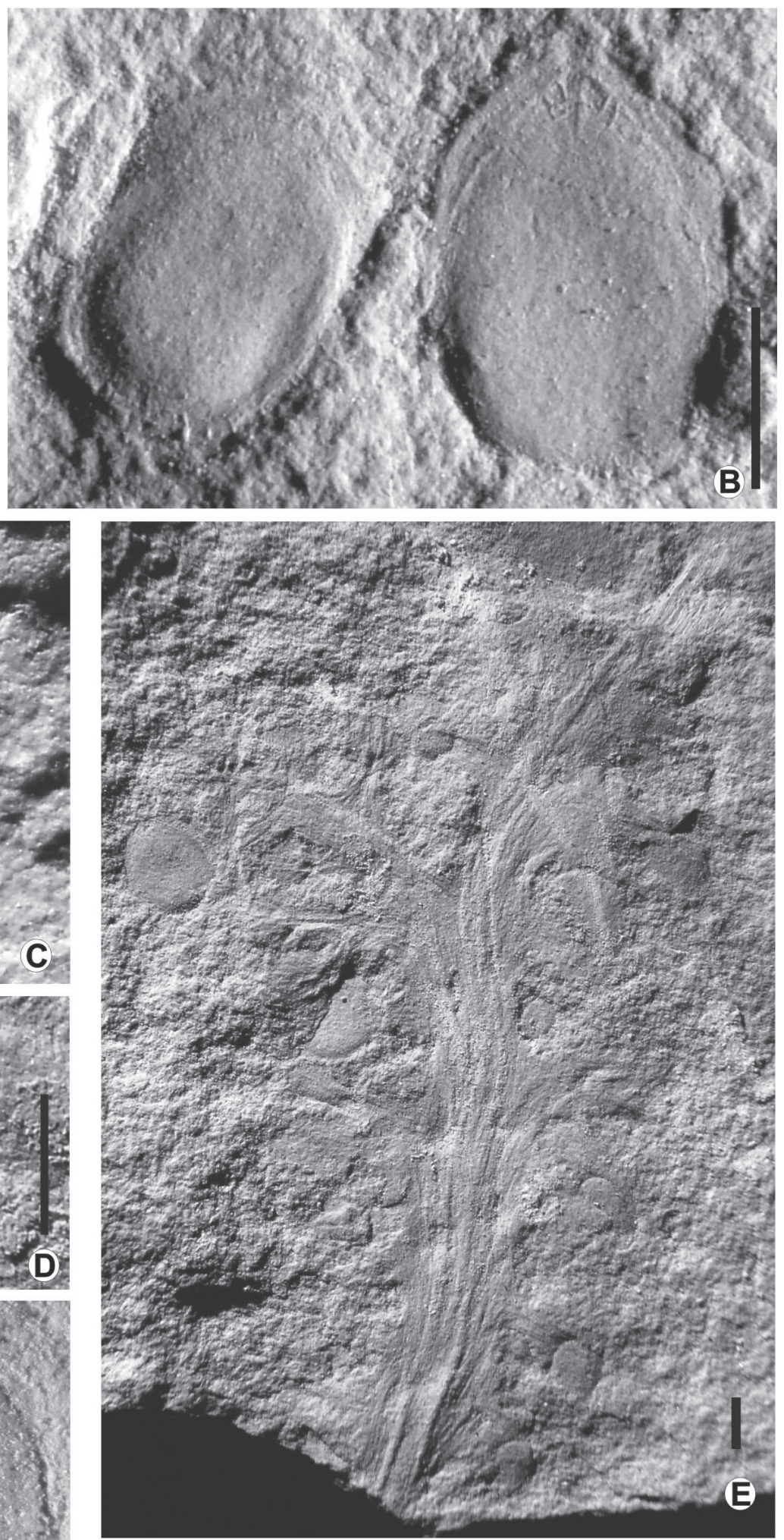

Figure 5. Cordaicarpus species. A, Cordaicarpus aff. C. famatinensis, MP-Pb 3980a, showing the testa thickening at the apical portion, and the emarginated micropyle; B, C. aff. C. famatinensis, MP-Pb 3696A-B; C, C. aff. C. famatinensis, MP-PB 3652A; D, C. aff. C. brasilianus, MP-Pb 3746, detail of the simplified seed structure; E, C. aff. C. brasilianus, MP-Pb 3746, fructification with the specimen MP$\mathrm{Pb} 3746 ; \mathbf{F}$, C. aff. C. brasilianus, MP-Pb 3950B, incomplete specimen, with a well-marked micropyle region; G, C. aff. C. brasilianus, MP$\mathrm{Pb} 3682 \mathrm{~A}$, complete specimen. Scale bars $=2 \mathrm{~mm}$. 
analysis becomes necessary to confirm the classification proposed herein.

\section{CONCLUDINGREMARKS}

The taxonomic study of the seed specimens found at the Morro do Papaléo, Faxinal Section and Cerro Negro outcrops from the Rio Grande do Sul State allowed the identification of four different morphotypes, two of them designated to species previously described to the genus Cordaicarpus, and the other two considered as new species of this same genus.

The first new morphospecies erected, Cordaicarpus cerronegrensis sp. nov., occurs at the Faxinal Section and Cerro Negro outcrops, positioned at the uppermost portion of the Itararé Group, dated as Late Sakmarian-Early Artinskian. The second one, Cordaicarpus truncata sp. nov., is restricted to the Morro do Papaléo outcrop at the uppermost portion of the Itararé Group (fossiliferous level N2), considered as Late Sakmarian in age. Thus, both new species are proposed for the uppermost portion of Itararé Group, waiting for a future confirmation of a possible geographic and stratigraphic extension in other areas or basins.

For the first time was recorded specimens similar to Cordaicarpus brasilianus, described to the upper portion of Itararé Group from Cerquilho locality, in São Paulo State, at the uppermost portion of Itararé Group in Rio Grande do Sul. In future, if confirmed the presence of $C$. brasilianus in the above-mentioned strata, this species would be extended its stratigraphic range up to the Rio Bonito Formation. The occurrence of specimens studied is restrict to Morro do Papaléo outcrop (fossiliferous level N4, N7 e N8), in a Late Sakmarian-Early Artinskian interval.

Finally, specimens similar to Cordaicarpus famatinensis, described originally to the Águas Coloradas Formation, Upper Carboniferous of Argentina, occur in the Lower Permian strata (Late Sakmarian in age) of the Morro do Papaléo outcrop (fossiliferous level N4), specifically at the upper portion of the Itararé Group. The definitive taxonomic assignation of these specimens remains doubtful due to the few material examined mainly. If confirmed the occurrence of $C$. famatinensis at the upper portion of the Itarare Group, the stratigraphic range of this species would be extended from Upper Carboniferous to Lower Permian, as well as the geographic distribution from northern Argentina to southern Brazil.

Considering the significant amount of seeds found at the fossil record, the present study should be a stimulus for many researchers deepen their studies on these dispersion structures and contribute for the enlargement of knowledge about floral paleocommunities and their reproductive strategies.

\section{ACKNOWLEDGMENTS}

The authors are thankful to F. F. Lopez (UFRGS) for the photographic material; to C. L. Baroni (UFRGS) for her help with the illustrations; and to Conselho Nacional
Desenvolvimento Científico e Tecnológico (proc. 309322/ 2007-3 and 483463/2007-8) and Fundação de Amparo à Pesquisa do Estado do Rio Grande do Sul (proc. 04/1066-0) for the finnantial support.

\section{REFERENCES}

Andreis, R.R.; Cazzulo-Klepzig, M.; Guerra-Sommer, M. \& Marques-Toigo, M. 1979. Interpretação paleoambiental e estudo paleobotânico e palinológico do Grupo Itararé, na área de Faxinal, Município de Guaíba, RS. In: SIMPÓSIO DE GEOLOGIA DO NORDESTE, 9, 1979. Atas, Natal, UFRN, p. 65- 77.

Archangelsky, A. 2000. Estudio sobre semillas neopaleozoicas de Argentina. Boletin de la Academia Nacional de Ciencias, 64:79115.

Bernardes-de-Oliveira, M.E.C.; Castro-Fernandes, M.C.; Tewari, R. \& Ricardi-Branco, F. 2007. Platyspermic seeds from the Early Permian of Paraná Basin, Brazil. The Palaeobotanist, 56:1-19.

Cazzulo-Klepzig, M. \& Guerra-Sommer, M. 1984. A paleoflora do Gonduana no Rio Grande do Sul. In: CONGRESSO BRASILEIRO DE GEOLOGIA, 18, 1984. Anais, Rio de Janeiro, SBG, v. 2, p. 1020-1022.

Cazzulo-Klepzig, M. \& Guerra-Sommer, M. 1985a. Plaeofloristic Gondwana succession in the Paraná Basin, Rio Grande do Sul, Southern Brasil. In: CONGRESSO LATINOAMERICANO DE GEOLOGIA, 6, 1985. Anais, Bogotá, SCG, p.177-192.

Cazzulo-Klepzig, M. \& Guerra-Sommer, M. 1985b. Relationship between the taphoflora of the Itatare Group, Paraná Basin, South Brasil and the Permocarboniferous boundary. In: CONGRESSO INTERNACIONAL DE ESTRATIGRAFIA Y GEOLOGIA DEL CARBONÍFERO, 10, 1985. Comptes rendus, Madrid, SGE, v. 2, p. 395-408.

Corrêa da Silva, Z.C. 1978. Observações sobre o Grupo Tubarão no Rio Grande do Sul com especial destaque à estratigrafía da Formação Itararé. Pesquisas, 9:9-61.

Corrêa da Silva, Z.C. \& Arrondo, O.G. 1977. Tafoflora Permiana de Mariana Pimentel, Município de Guaíba, Rio Grande do Sul. Pesquisas, 7:27-44.

Delaney, P.J.V. 1964. Itararé outliers in Rio Grande do Sul, Brasil. Boletim Paranaense de Geografia, 10:161-171.

Guerra-Sommer, M. \& Cazzulo-Klepzig, M. 1981. A tafoflora do grupo Itararé no Rio Grande do Sul: sua importância bioestratigráfica no Gonduana Sulbrasileiro. In: CONGRESSO LATINOAMERICANO DE PALEONTOLOGIA, 2, 1981. Anais, Porto Alegre, UFRGS, v. 1, p. 127-140.

Guerra-Sommer, M. \& Cazzulo-Klepzig, M. 1993. Biostratigraphy of the Southern Brazilian Neopaleozoic Gondwana Sequence: A preliminary palaeobotanical approach. In: INTERNATIONAL CONGRÉS DE LA STRATIGRAPHIE ET GÉOLOGIE DU CARBONIFÉRE ET PERMIEN, 12, 1993. Comptes rendus, Buenos Aires, AGA, v. 2, p. 61-72.

Guerra-Sommer, M. \& Cazzulo-Klepzig, M. 2000. As floras gonduânicas do Paleozóico Superior do Rio Grande do Sul. In: M. Holz \& L.F. de Ros (eds.) Paleontologia do Rio Grande do Sul. CIGO/UFRGS, p. 67-84.

Guerra-Sommer, M.; Cazzulo-Klepzig, M. \& Marques-Toigo, M. 1980. Revisão fitoestratigráfica do Grupo Itararé no Rio Grande do Sul. III-Área de Faxinal, município de Guaíba, Rio Grande do Sul. Boletim do IG-USP, 11:31-189.

Gutierrez, P.R.; Ganuza, D.G.; Morel, E. \& Arrondo, O.G. 1992. 
Los generos Cordaicarpus Arber y Samaropsis Goeppert (Semillas Platispérmicas) en el Neopaleozoico argentino. Ameghiniana, 29(1):49-68.

Høeg, O.V. \& Bose, M.N. 1960. The Glossopteris Flora of the Belgian Congo, with a note on some fossil plants from the Zambesi Basin (Mozambique). Annales du Musée du Congo Belge, Sciences Géologiques, 32:1-107.

Iannuzzi, R.; Marques-Toigo, M.; Scherer, C.M.S.; Caravaca, G; Vieira, C.E.L. \& Pereira, L.S. 2003a. Reavaliação da fitobioestratigrafia da seqüência gondwanica sul-riograndense: estudo de caso do afloramento Morro do Papaléo (Bacia do Paraná, Permiano Inferior). In: ENCONTRO SOBRE ESTRATIGRAFIA DO RIO GRANDE DO SUL: ESCUDOS E BACIAS, 1, 2003. Anais, Porto Alegre, UFRGS, p. 182-185. Iannuzzi, R.; Marques-Toigo, M.; Scherer, C.M.S.; Caravaca, G; Vieira, C.E.L. \& Pereira, L.S. 2003b. Phytobiostratigraphical revaluation of the southern Brazilian Gondwana sequence (Paraná Basin, Lower Permian). In: INTERNATIONAL CONGRESS ON CARBONIFEROUS AND PERMIAN STRATIGRAFY, 15, 2003. Abstracts, Utrecht, p. 240-242.

Iannuzzi, R.; Scherer, C.M.S.; Souza, P.A., Holz, M.; Caravaca, G.; Adami-Rodrigues, K.; Tybusch, G.P.; Souza, J.M.; Smaniotto, L.P.; Fischer, T.V.; Silveira, A.S.; Lykawka, R.; Boardman, D.R. \& Barboza, E.G. 2006. Afloramento Morro do Papaléo, Mariana Pimentel, RS. Registro ímpar da sucessão pós-glacial do Paleozóico da Bacia do Paraná. <http:// www.unb.br/ig/sigep/sitio101/sitio101.pdf>

Iannuzzi, R.; Scherer, C.M.S. \& Caravaca, G. 2007. Taphonomy and paleoecology of the southern Brazilian Glossopteris Flora (Paraná Basin, Lower Permian). Cuadernos del Museo Geominero, 8:201-206.

Lele, K.M. 1963. Studies in the Indian Middle Gondwana Flora: 3. Platispermics seeds and megaspore impressions from the South Rewa Gondwana Basin. The Palaeobotanist, 11(1/2):13-18.

Maithy, P.K. 1965. Studies in the Glossopteris flora of India: 18. Gymnospermic seeds and seed-bearing organs from the Karharbari beds of the Giridih coalfield, Bihar. The Palaeobotanist, 13(1):45-56.

Millan, J.H. 1965. Considerações sobre as sementes do Carbonífero do Brasil. Rio de Janeiro, Departamento Nacional da Produção Nacional, Divisão de Geologia e Mineralogia, 18 p. (Boletim 123).
Millan, J.H. 1967. O gênero Samaropsis na flora do Gondwana do Brasil e de outros países. Rio de Janeiro, Museu Nacional, 11 p. (Boletim 32).

Millan, J.H. 1974. As sementes platispérmicas do Gondwana face ao Esquema Maithy. Anais da Academia Brasileira de Ciências, 46(3/4):538-547.

Millan, J.H. 1977a. Sementes platispérmicas da flórula gondwanica de Monte Mor, Estado de São Paulo, Brasil. Ameghiniana, 14(1/4):33-44

Millan, J.H. 1977b. Sementes platispérmicas do eogondwana de Cerquilho, São Paulo, (Bacia do Paraná). Anais da Academia Brasileira de Ciências, 49(4):581-595.

Millan, J.H. 1980. Sobre uma possível utilização estratigráfica de sementes gondvânicas. Anais da Academia Brasileira de Ciências, 52(2):353-358.

Millan, J.H. 1994. O esquema de identificação e classificação das sementes gondvânicas: reatualização e análise crítica. Anais da Academia Brasileira de Ciências, 66(4):475-488.

Millan, J.H. 1995. Novas ocorrências de sementes platispérmicas em tafofloras associadas à camadas carbonosas do Grupo Tubarão, eogondwana da Bacia do Paraná, no Estado de São Paulo. Anais da Academias Brasileira de Ciencias, 67(1):117-128.

Oliveira, M.E.C.B. \& Pontes, C.E.S. 1976. Algumas observações sobre cordaitófitas da Formação Rio Bonito. Grupo Tubarão Bacia do Paraná Brasil. In: CONGRESSO GEOLÓGICO CHILENO, 1, 1976. Actas, Santiago, SGC, v. 3, p. L22-L81.

Seward, A.C. 1917. Fossil Plants V.III. London, Cambridge Biology Series, $656 \mathrm{p}$.

Souza, J.M. \& Iannuzzi, R. 2007. Sementes do gênero Samaropsis Goeppert no Permiano Inferior da Bacia do Paraná, sul do Brasil. Revista Brasileira de Paleontologia,10(2):93-106.

Taylor, T.N. \& Taylor, E.L. 1993. The Biology and Evolution of Fossil Plants. New Jersey, Prentice Hall, 982 p.

Walkom, A.B. 1935. Some fossil seeds from the upper Paleozoic rocks of the Werrie Basin, N.S.W. Proceedings of the Linnean Society of New South Wales, 60:459-463.

White, D. 1908. Fossil flora of the coal measures of Brazil. In: I.C. White (ed.) Comissão de Estudos das Minas de Carvão de Pedra do Brasil, Relatório Final, p. 558-568.

Zeiller, R. 1902. Observation sur quelques plants fossiles des Lower Gondwanas. Memoirs of the Geological Survey of India, Palaeontologia Indica. N.S., 2:1-40.

Received in September, 2008; accepted February, 2009. 